\title{
Bract Necrosis: A Non-parasitic Disease of Sunflower*
}

\author{
Shaw-ming YANG** and Robert W. BERRY*** \\ Shaw-ming $\mathrm{YANG}_{\mathrm{AN}}$ * Robert W. BerRY***: ヒマワリの \\ 非奇生性病害, 花盤のネクロシス*
}

Key Words: Helianthus annuus, physiological disease.

Brown-black discoloration (bract necrosis) of involucral bracts and disk flowers of sunflower (Helianthus annuus L.) occurred on the Texas High Plains in 1979, 1980 and 1981. Bract necrosis of sunflower also occurred in South Africa (T. C. Heaton, personal communication) and in Spain. Bract necrosis is also found on plants grown in the greenhouse during the hot summer. The current paper describes symptoms and causes of bract necrosis on sunflower.

Typical symptoms included brown to brown-black discoloration of bracts (Fig. 1) and disk flowers. The discolored bracts subsequently became dry and hard. The brown discoloration became black after rain. Ray flowers adjacent to necrotic bracts failed to devlop or they developed abnormally and fell prematurely. Buds often died

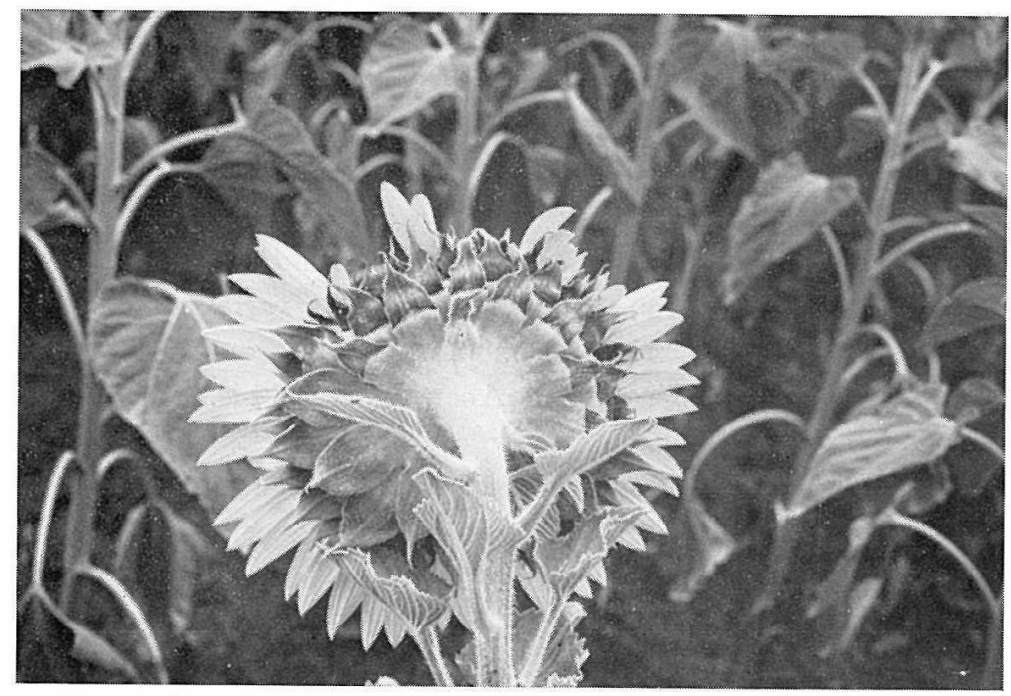

Fig. 1. Bract necrosis of sunflower. Some ray flowers did not develop near necrotic bracts.

\footnotetext{
* Contribution from USDA, Agricultural Research Service, in cooperation with The Texas Agricultural Experiment Station, Texas A \& M University, College Station, Texas 79012.

** USDA-ARS, Conservation and Production Research Laboratory, Bushland, Texas 79012. *** Texas Agricultural Extension Service, Lubbock, Texas 79401.
} 


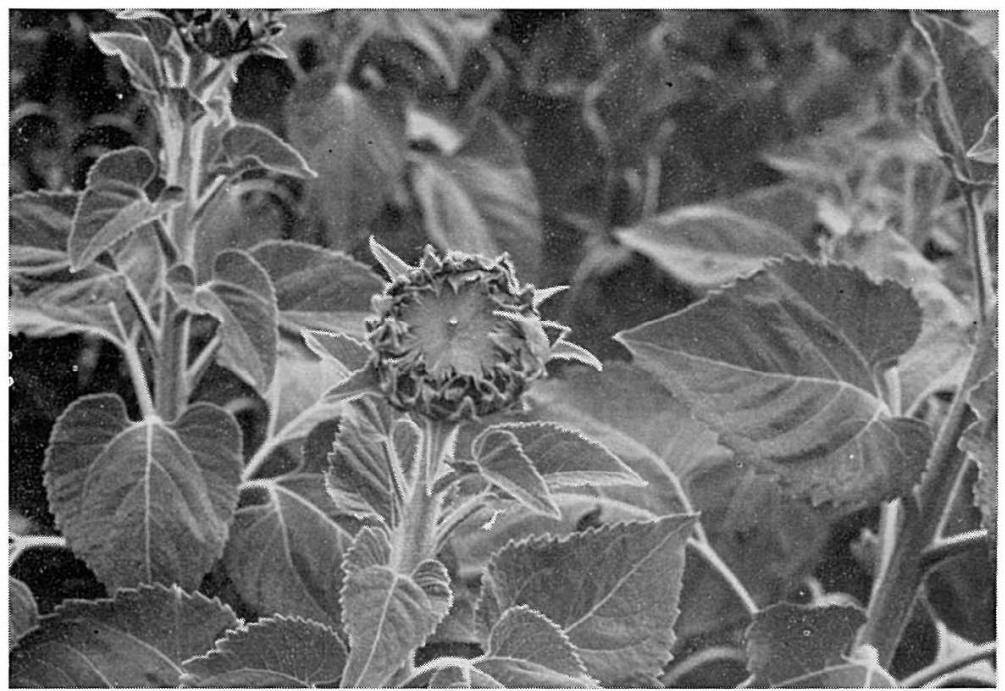

Fig. 2. An opened sunflower bud with necrotic bracts showing. Notice the absence of both ray flowers and disk flowers.

before they opened when bract necrosis occurred during budding stages of plant phenology. Also, some affected buds opened but produced few disk flowers with little pallen. Others produced neither ray flowers nor disk flowers (Fig. 2).

Bract necrosis occurred only on dryland (non-irrigated) sunflower after the budding stages [R stages $]^{1)}$ when the daily air temperature was at or above $35 \mathrm{C}$ for a period of several days. Bract necrosis developed in a single plant or several contagious plants in a row, or several plants in the vicinity in two or three rows. Sunflower plants receiving adequate water during budding and anthesis stages [R1 to R6 stages] ${ }^{1)}$ did not develop bract necrosis. Alternaria alternata (Fries) Keissler, Curvularia lunata (Wakker) Boedign, Fusarium solani (Martius) Saccardo, and Rhizopus arrhizus Fischer were isolated on potato-dextrose agar (PDA) from the surface-sterilized tissues of necrotic bract and disk flowers ( $3 \mathrm{~min}$ in $0.1 \% \mathrm{NaOCl}$ solution) but no fungi were isolated from the bracts soon after the necrosis appeared. However, isolates of these fungi did not cause bract necrosis when spore suspensions $\left(10^{5}\right.$ spores $\left./ \mathrm{ml}\right)$ of these isolates were atomized on the heads of sunflower ( 10 heads per isolate in two experiments) during the budding [R 1 to $\mathrm{R} 4$ stages $]^{1)}$ and anthesis stages $[\mathrm{R} 5 \text { stage }]^{13}$ in the greenhouse (25-33 C) even though the inoculated sunflower heads were covered with plastic bags for five to seven days.

Ten sunflower heads detached from plants at anthesis stages and their peduncles immersed in tap water in flasks were inoculated with $R$. arrhizus by the insertion inoculation technique ${ }^{2}$, and incubated in a growth chamber $(45 \mathrm{C}$ for $14 \mathrm{hr}$ and $35 \mathrm{C}$ in darkness for $10 \mathrm{hr}$ daily). The sunflower heads were not covered with plastic bags after inoculation. Brown lesions developed on the receptacles and necrosis on some bracts near and also away from the site of inoculation within three days. When 10 sunflower heads inoculated with $R$. arrhizus were covered with plastic bags and

1) Schneiter, A. A. and Miller, J. G. (1981). Crop Sci. 21: 901-903. 2) Yang, S. M. and Thomas, C.A. (1980). Ann. Phytopath. Soc. Japan 46:553-555. 
incubated in the same growth chamber, the entire receptacle and most of the bracts became necrotic within three days. Longitudinal sections of the inoculated heads showed that most of the tissues in the receptacles were not infected by Rhizopus. Neither Rhizopus nor other fungus was isolated on PDA from surface-sterilized tissues of the necrotic bracts taken from the non-Rhizopus infected areas. Eight out of ten sunflower heads, not inoculated with any fungus, kept in the same growth chamber, developed bract necrosis within three days. No fungus was isolated from the surface-sterilized tissues taken from these discolored bracts.

In another experiment, 20 sunflower heads were detached from plants at budding and anthesis stages and their peduncles were immersed in tap water in flasks in a $40 \mathrm{C}$ growth chamber ( $14 \mathrm{hr}$ light and $10 \mathrm{hr}$ darkness). Brown discoloration of bracts appeared within a week. No fungus was isolated in PDA from surface-sterilized tissues taken from the discolored bracts. Detached sunflower heads with peduncles immersed in tap water at room temperature $(20 \pm 2 \mathrm{C})$ or in a growth chamber at $30 \mathrm{C}$ served as controls and showed no brown discoloration of the bract in a week. We interpret these results to indicate that symptoms of bract necrosis of sunflower is due to moisture/heat stress and not to parasitic fungi. 